\title{
Thyroid function in post-weaning rats whose dams were fed a low-protein diet during suckling
}

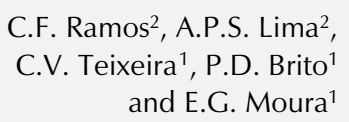

1Departamento de Ciências Fisiológicas, Instituto de Biologia and

${ }^{2}$ Departamento de Ciências, Faculdade de Formação de Professores de São Gonçalo, Universidade do Estado do Rio de Janeiro, 20550-030 Rio de Janeiro, RJ, Brasil
Correspondence

E.G. Moura

Departamento de Ciências

Fisiológicas

Instituto de Biologia, UERJ

Av. 28 de setembro, 87

20550-030 Rio de Janeiro, RJ

Brasil

Fax: 55 (021) 587-6530

E-mail:

egmoura@mi.montreal.com.br

Presented at the XI Annual Meeting of the Federação de Sociedades de Biologia Experimental, Caxambu, MG, Brasil, August 21-24, 1996.

Research supported by CNPq (No. 520967/94-1).

Received April 10, 1996 Accepted November 11, 1996 Accepted November 11,1996

\begin{abstract}
This study was designed to evaluate the thyroid and pituitary hormone levels in post-weaning rats whose dams were fed a low-protein diet during suckling (21 days). The dams and pups were divided into 2 groups: a control group fed a diet containing $22 \%$ protein that supplies the necessary amount of protein for the rat and is the usual content of protein in most commercial rat chow, and a diet group fed a lowprotein $(8 \%)$ diet in which the protein was substituted by an isocaloric amount of starch. After weaning all dams and pups received the $22 \%$ protein diet. Two hours before sacrifice of pups aged 21, 30 and 60 days, a tracer dose $(0.6 \mu \mathrm{Ci})$ of ${ }^{125}$ I was injected ( $\left.i p\right)$ into each animal. Blood and thyroid glands of pups were collected for the determination of serum $\mathrm{T}_{4}, \mathrm{~T}_{3}$ and $\mathrm{TSH}$ and radioiodine uptake. Low protein diet caused a slight decrease in radioiodine uptake at 21 days, and a significant decrease in $\mathrm{T}_{3}$ levels $(128 \pm 14$ vs $74 \pm 9 \mathrm{ng} / \mathrm{dl}, \mathrm{P}<0.05)$, while $\mathrm{T}_{4}$ levels did not change and $\mathrm{TSH}$ was increased slightly. At 30 days, $\mathrm{T}_{3}$ and TSH did not change while there was a significant increase in both $\mathrm{T}_{4}$ levels $(4.8 \pm 0.3$ vs $6.1 \pm 0.2 \mu \mathrm{g} / \mathrm{dl}, \mathrm{P}<0.05)$ and in radioiodine uptake levels $(0.34 \pm 0.02$ vs $0.50 \pm 0.03 \% / \mathrm{mg}$ thyroid, $\mathrm{P}<0.05)$. At 60 days serum $\mathrm{T}_{3}, \mathrm{~T}_{4}$ and $\mathrm{TSH}$ levels were normal, but radioiodine uptake was still significantly increased $(0.33 \pm 0.02 \mathrm{vs}$ $0.41 \pm 0.03 \% / \mathrm{mg}$ thyroid, $\mathrm{P}<0.05)$. Thus, it seems that protein malnutrition of the dams during suckling causes hypothyroidism in the pups at 21 days that has a compensatory mechanism increasing thyroid function after refeeding with a $22 \%$ protein diet. The radioiodine uptake still remained altered at 60 days, when all the hormonal serum levels returned to the normal values, suggesting a permanent change in the thyroid function.
\end{abstract}

Several changes in thyroid economy are detected in food-restricted animals. Thyroid hormone secretion (1) and metabolism $(2,3)$, as well as thyroid regulation by hypothalamic and pituitary hormones $(4,5)$ are impaired in this situation. Similar changes were reported for protein-deprived adult humans $(6,7)$ and animals $(8,9)$.
Key words

- Thyroid

- Protein malnutrition

- Lactation

- Thyrotropin

- Thyroid hormones
Protein restriction causes changes in milk composition and volume of the lactating dams $(10,11)$. However, few studies have evaluated the effects of food restriction or protein malnutrition on the dams or on the thyroid function of fetuses or newborns and most of them encompassed both the gestation and lactation periods. 
During gestation, protein malnutrition causes a delay in thyroid follicle formation and a reduction in gland area, follicle number, colloid space and cell size in the thyroid tissue of fetal and neonatal pups from protein-deprived dams (12). A decrease in $\mathrm{T}_{3}$ level with normal serum $\mathrm{T}_{4}$ and thyroid stimulating hormone (TSH) levels was shown in the fetuses or newborns from protein-deprived lactating dams $(13,14)$. Oberkotter and Rasmussen (15) reported that the offspring of chronically food-restricted dams showed a decrease in serum $\mathrm{T}_{3}$ and an increase in serum reverse $T_{3}\left(\mathrm{rT}_{3}\right.$, an inactive metabolite of $\mathrm{T}_{4}$ ) levels in 7-, 14- or 21-day old animals and a decrease in $\mathrm{T}_{4}$ only in the 14-day old animals.

To our knowledge, no study was performed to evaluate the effect of protein malnutrition during lactation on the thyroid function of the offspring. Therefore, we investigate here, for the first time, the importance of an adequate protein supply during suckling for the establishment of normal regulatory function of the hypothalamic-pituitarythyroid axis.

Wistar rats bred in our laboratory in a room with controlled temperature and an artificial dark-light cycle (lights on from 7:00 to 19:00 h) were used throughout the study. Virgin female rats, 3 months of age, were caged with one male rat at a proportion of $2: 1$. After mating, each female was placed in an individual cage with water and food $a d$ libitum until delivery. Each dam was kept with only 6 pups, because it was previously demonstrated that this procedure produces maximum lactation performance (11). The dams were randomly divided into 2 groups: a control group (C) that received a standard laboratory diet containing (in grams per 100 g) 22 protein, 65 carbohydrate, 5 lipid and 5 cellulose, and a protein-deprived group (D) receiving an isocaloric and protein-restricted diet (8\% protein) that was replaced by starch in the same amount of calories as the protein deprivation; all other components of the diet including vitamins and salts were equal to those in the control diet (16). Malnutrition was established on the day of birth and maintained throughout the lactation period (21 days). After weaning all dams and pups received the control diet until sacrifice.

Approximately 150 pups, 21, 30 or 60 days old, were evaluated. At these times, all animals received $0.6 \mu \mathrm{Ci}$ of ${ }^{125} \mathrm{I} i p$, and $2 \mathrm{~h}$ later they were killed with a lethal dose of ether (1). Blood samples were taken by cardiac puncture and centrifuged and the serum was separated individually for all groups, except for the 21-day old pups whose sera were pooled (pool of 6 animals). Total serum $T_{4}$ and $T_{3}$ levels were measured by radioimmunoassay (RIA) using commercial kits (Coat-A-Coat, DPC, Los Angeles, USA), in which we used control standard curves diluted in iodothyronine-free rat serum. The assays were validated since the values for these controls were almost superimposed on the kit standard curve. Serum TSH was measured by RIA using a specific rat TSH kit supplied by the NIDDK (Bethesda, USA, rp3). Thyroid glands were excised and weighed and thyroidal ${ }^{125}$ I uptake was individually determined with a gammacounter (Cobra Auto-gamma, Packard Instrument Co., Downers Grove, USA). The data are reported as mean \pm SEM. Statistical comparisons were performed by the Student $t$-test, with the level of significance set at $\mathrm{P}<0.05$.

The pups from protein-deprived dams presented a significantly $(\mathrm{P}<0.05)$ lower body weight on all days studied $\left(\mathrm{C}_{21}=37.2 \pm 0.1\right.$ vs $\mathrm{D}_{21}=13.5 \pm 0.1 ; \mathrm{C}_{30}=69.8 \pm 1.0$ vs $\mathrm{D}_{30}=$ $32.4 \pm 0.8 ; \mathrm{C}_{60}=166.9 \pm 3.5$ vs $\mathrm{D}_{60}=130.4$ $\pm 2.2 \mathrm{~g}$ ). After weaning and feeding a control diet, the $\mathrm{D}$ pups showed a higher weight gain rate, which reduced the difference in weight between the two groups $(64 \%, 54 \%$ and $22 \%$, percentage of control at 21,30 and 60 days, respectively). We also found a significant $(\mathrm{P}<0.05)$ reduction in thyroid weight of $\mathrm{D}$ pups $\left(\mathrm{C}_{21}=3.8 \pm 0.1 v s \mathrm{D}_{21}=1.4 \pm 0.1 ; \mathrm{C}_{30}\right.$ $=5.5 \pm 0.1 v s \mathrm{D}_{30}=2.7 \pm 0.1 ; \mathrm{C}_{60}=13.0 \pm 0.4$ 
$v s \mathrm{D}_{60}=9.6 \pm 0.3 \mathrm{mg}$ ), but the thyroid weight/ body weight ratios were normal at the $21 \mathrm{st}$ and 60th days and increased at the 30th day, suggesting a sparing action on gland growth $\left(\mathrm{C}_{21}=10.1 \pm 0.3\right.$ vs $\mathrm{D}_{21}=10.5 \pm 0.9 ; \mathrm{C}_{30}=$ $7.9 \pm 0.2 v s \mathrm{D}_{30}=8.4 \pm 0.2, \mathrm{P}<0.05 ; \mathrm{C}_{60}=7.8$ \pm 0.3 vs $\left.\mathrm{D}_{60}=7.4 \pm 0.2 \mathrm{mg} / \mathrm{g}\right)$. It was also reported by Shrader et al. (14) that the thyroid glands of the fetuses from protein-deprived rats showed a smaller weight, but they did not observe changes in the thyroid weight/body weight ratio. Thus, it seems that after birth compensatory mechanisms are more efficient than during the fetal period.

Protein deprivation of the dams caused a slight decrease in the ${ }^{125} \mathrm{I}$ thyroid uptake at 21 days, and a significant $(\mathrm{P}<0.05)$ increase at 30 and 60 days (Figure 1) in the pups. Total serum $\mathrm{T}_{4}$ levels (Figure 2, panel B) showed a rather similar pattern, i.e., they were slightly decreased $(11 \%)$ at the $21 \mathrm{st}$ day, significantly increased (21\%) at the 30th day, corresponding to nine days of control diet, and normal at the 60th day of life. These data may explain, at least in part, our findings of a significant decrease of approximately $42 \%$ in serum $\mathrm{T}_{3}$ at 21 days (Figure 2, panel A). The animals showed a fast recovery in serum $\mathrm{T}_{3}$ levels, with not statistically significant high levels in the diet group 9 days after the introduction of the control diet. Serum TSH levels only increased (37\%) in 21 day-old pups but this difference was not statistically significant (Figure 2, panel C).

Our findings are the first to indicate that feeding dams a low-protein diet only during the lactation period causes changes in the thyroid function of the offspring. Similar results were reported by others $(13,14)$, who induced protein malnutrition in rats during the gestational period and reported low serum $\mathrm{T}_{3}$ with normal serum $\mathrm{T}_{4}$ and TSH concentrations in fetuses and newborns. They are also consistent with the results of Oberkotter and Rasmussen (15) who evaluated the effect of food restriction in dams that were submitted to a low-calorie diet after they were 42 days old throughout the nursing period. Despite the longer period of food restriction, their data about serum $\mathrm{T}_{3}$ and $\mathrm{T}_{4}$ levels are similar to ours, showing that the lactation period was critical in deter-

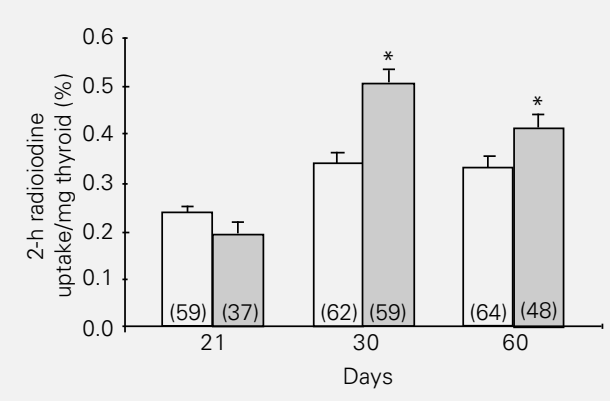

Figure $1-{ }^{125}$ I uptake by the thyroid of 21, 30 and 60-day old rats whose dams were fed a lowprotein diet $(8 \%)$ during their suckling period. Data are reported as percent of the total radioiodine administered per $\mathrm{mg}$ of thyroid tissue (mean \pm SEM). The number of thyroids is given in parentheses inside the bars. Dams were fed a control ( $\square$ ) or low-protein diet (ㅁ) during suckling. ${ }^{*} \mathrm{P}<0.05$ compared to the control group whose dams were fed a standard control diet (22\%) (Student $t$-test).
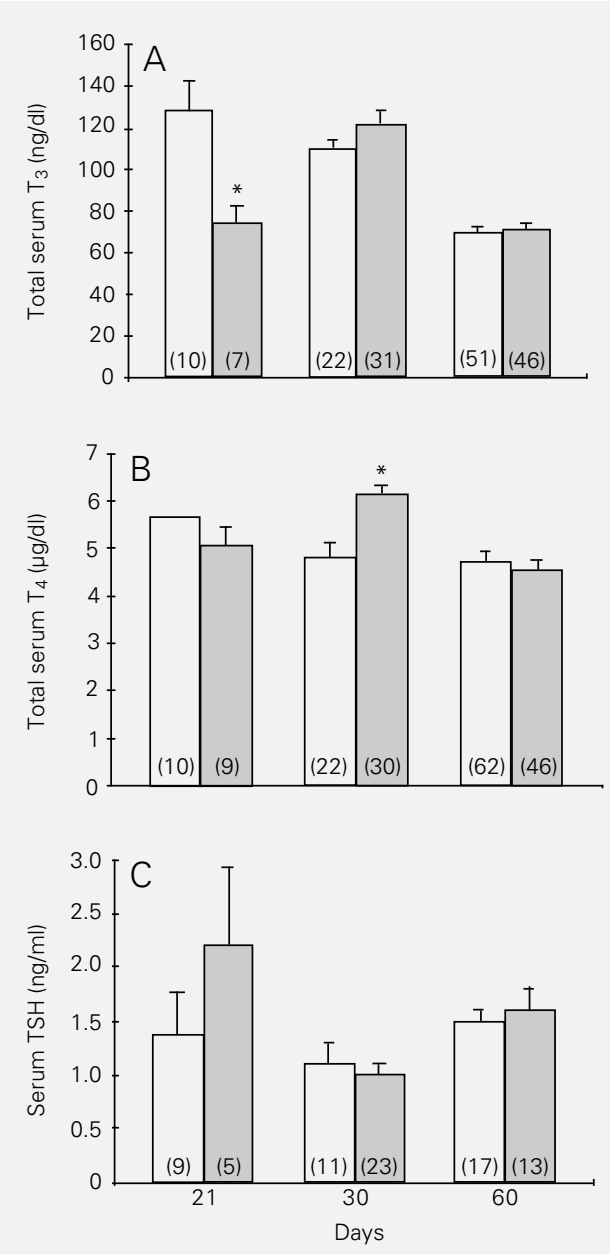

Figure 2 - Serum $T_{3}, T_{4}$ and TSH levels of 21, 30 and 60-day old rats whose dams were fed a low-protein diet $(8 \%)$ during their suckling period. Data are reported as ng/dl for $T_{3}$ (panel A), $\mu \mathrm{g} / \mathrm{dl}$ for $\mathrm{T}_{4}$ (panel B) and $\mathrm{ng} /$ $\mathrm{ml}$ for TSH (panel C) and are reported as mean \pm SEM. The number in parentheses inside the bars corresponds to the number of animals, except for the 21-day old groups in which this number corresponds to the number of pools of serum from 6 animals. Dams were fed a control () or low-protein (口) diet during suckling. ${ }^{*} \mathrm{P}<0.05$ compared to the control group whose dams were fed a standard control diet (22\%) (Student $t$-test). 
mining these changes on the thyroid function.

The present data show that protein malnutrition during suckling changes thyroid function in the pups, and in the 21-day old animals these changes suggest primary hypothyroidism, since thyrotropin did respond to the low $\mathrm{T}_{3}$ levels. Also, despite the increase of TSH at this time, ${ }^{125}$ I uptake by the thyroid did not increase, but was slightly decreased.

The fast recovery of thyroid function only nine days after feeding a control diet was remarkable. At this time, the animals from group D showed a compensatory increase in ${ }^{125} \mathrm{I}$ thyroid uptake and serum $\mathrm{T}_{4}$ levels, and a slight increase in $T_{3}$. However, these changes did not affect TSH. Except for radioiodine uptake, all parameters studied returned to normal values after 39 days of normal diet. It is possible that protein malnutrition in the nursing mothers causes permanent changes in the thyroid function of their offspring, since radioiodine uptake continued to be high in these animals even 39 days post-weaning.

Food restriction does impair $\mathrm{T}_{4}$ to $\mathrm{T}_{3}$ conversion by decreasing $5^{\prime}$-monodeiodinase activity (3), which could explain the low levels of $\mathrm{T}_{3}$ in 21-day old rats. Kliewer and
Rasmussen showed (17) that food restriction increased corticosterone levels in the milk and, since corticosterone decreases 5'monodeiodinase, it may act as one of the mediators of the impairment of $\mathrm{T}_{4}$ to $\mathrm{T}_{3}$ conversion in this particular situation. The slight decrease in total serum $\mathrm{T}_{4}$ may be due to a lower thyroidal secretory rate or lower levels of serum-binding proteins in the rat, since recently Rouaze-Romet et al. (8) showed that the levels of thyroxine-binding globulin and the serum thyroid hormonebinding activity increased in rats submitted to a protein-restricted diet, despite the decrease in transthyretin, the main thyronine transporter protein in rat plasma. Since the metabolic rate of $\mathrm{T}_{4}$ can also be decreased by relative hypothyroidism and by a decrease in the deiodinative pathway of $\mathrm{T}_{4}$, despite the compensatory increase of $\mathrm{rT}_{3}$ formation, this may be counteracting a possible decrease in thyroid $\mathrm{T}_{4}$ secretion, explaining why total serum $\mathrm{T}_{4}$ did not decrease significantly.

Independent of the nutritional status of the offspring nursed by protein-deprived mothers, the modifications in the milk composition of protein-deprived mothers cause changes in thyroid function that are not completely reversed till the animals reach the age of 60 days.

\section{References}

1. Moura EG, Ramos CF, Nascimento CCA, Rosenthal D \& Breitenbach MMD (1987). Thyroid function in fasting rats: variations in ${ }^{131}$ I uptake and transient decrease in peroxidase activity. Brazilian Journal of Medical and Biological Research, 20: 407410.

2. Harris $A R C$, Fang $S L$, Vagenakis $A G$ \& Braverman LE (1978). Effect of starvation, nutrient replacement and hypothyroidism on in vitro hepatic $T_{4}$ to $T_{3}$ conversion in the rat. Metabolism, 27: 1680-1690.

3. Chopra IJ (1980). Alterations in monodeiodination of iodothyronine in the fasting rat. Effect of reduced nonprotein sulfhydryl groups and hypothyroidism. Metabolism, 29: 161-167.
4. Harris $A R C$, Fang $S L$, Azizi F, Lipworth $L$, Vagenakis AG \& Braverman LE (1978). Effect of starvation on hypothalamic-pituitary-thyroid function in the rat. Metabolism, 27: 1074-1083.

5. Jolin T \& Lamas L (1984). Thyroid function in fasting rats. Diabetes, 33: 383-388.

6. Chopra IJ \& Smith SR (1975). Circulating thyroid hormones and thyrotropin in adult patients with protein-calorie malnutrition. Journal of Clinical Endocrinology and Metabolism, 40: 221-227.

7. Rastogi GK, Sawhney RC, Panda NC \& Tripathy BB (1974). Thyroid hormone levels in adult protein-calorie malnutrition (PCM). Hormone and Metabolic Research, 6: 528-529.
8. Rouaze-Romet M, Savu L, Vranckx R, Bleiberg-Daniel F, Le Moullac B, Gouache $P$ \& Nunez EA (1992). Re-expression of thyroxine-binding globulin in post-weaning rats during protein or energy malnutrition. Acta Endocrinologica, 127: 441-448.

9. Rostom de Mello MA, Oliveira Filho RM, Cury L \& Valle LBS (1989). Circulating thyroid hormone levels in young pregnant rats and their fetuses: Effect of malnutrition. Annals of Nutrition and Metabolism, 33: 181-187.

10. Pine AP, Jessop NS \& Oldham JD (1994) Maternal protein reserves and their influence on lactational performance in rats: The effects of dietary protein restriction and stage of lactation on milk composition. Journal of Nutrition, 72: 815-830. 
11. Fischbeck KL \& Rasmussen KM (1987). Effect of repeated reproductive cycles on maternal nutritional status, lactational performance and litter growth in ad libitumfed and chronically food-restricted rats. Journal of Nutrition, 117: 1967-1975.

12. Shrader RE, Hastings-Roberts MM, Ferlatte MI \& Zeman FJ (1977). Effect of prenatal protein deprivation on fetal and neonatal thyroid morphology in the rat. Journal of Nutrition, 107: 213-220.

13. Friedman DJ \& Zeman F (1979). Thyroid, pituitary, and hypothalamic hormone levels in neonatal rat pups following maternal protein deficiency. Proceedings of the Society for Experimental Biology and Medicine, 16: 275-279.
14. Shrader RE, Ferlatte MI, HastingsRoberts MH, Schoenborne BM, Hoernicke CA \& Zeman FJ (1977). Thyroid function in prenatally protein-deprived rats. Journal of Nutrition, 107: 221-229.

15. Oberkotter LV \& Rasmussen KM (1992). Changes in plasma thyroid hormone concentration in chronically food-restricted female rats and their offspring during suckling. Journal of Nutrition, 122: 435441.
16. Barbosa FB, Gravena C, Mathias P \& Moura AS (1993). Blockade of the 32p phosphate flush of pancreatic beta cells from adult rats who received a low-protein diet during early lactation. Brazilian Journal of Medical and Biological Research, 26: 1355-1358.

17. Kliewer RL \& Rasmussen KM (1987). Malnutrition during the reproductive cycle: effects on galactopoietic hormones and lactational performance in the rat. American Journal of Clinical Nutrition, 46: 926935. 